\title{
Effect of integrated nutrient management on fruit quality of pomegranate cv. Ganesh
}

\author{
CL Meena, RK Meena, DK Sarolia, LK Dashora \& D Singh
}

Journal of Agriculture and Ecology

Volume-5 (June, 2018)

ISSN: $2456-9410$

\section{Journal of Agriculture}

and Ecology

ISSN: 2456-9410

Volume: 5

Journal of Agriculture and Ecology (2018) 5: 67-75

http://doi.org/10.53911/JAE.2018.5108 


\title{
Effect of integrated nutrient management on fruit quality of pomegranate cv. Ganesh
}

\author{
CL Meena, RK Meena* $\sqsubset$, DK Sarolia*, LK Dashora \& D Singh**
}

Department of Horticulture, Rajasthan College of Agriculture, Udaipur-313 001

* ICAR-Central Institute for Arid Horticulture, Bikaner- 334006

** Department of Horticulture, KA PG College, Allahabad (UP), India

Corresponding author: RK Meena, E-mail rkmeena8119@yahoo.com

\begin{tabular}{l}
\hline Article Info \\
\hline Article history \\
Received: 10 May \\
2018 \\
Accepted: 30 May \\
2018 \\
Available online: 15 \\
June 2018
\end{tabular}

Key Words: INM, vermicompost, FYM, biofertilizers, fruit quality, pomegranate.

\begin{abstract}
A field experiment was conducted with integrated nutrient management treatments on 5 year old pomegranate $\mathrm{cv}$. Ganesh. Total treatment combinations were seventeen viz, $\mathrm{T}_{1}$-Recommended dose of NPK i.e. 500 : 200: $500 \mathrm{~g}$ NPK/plant, $\mathrm{T}_{2^{-}}$Vermicompost $(10 \mathrm{~kg} / \mathrm{plant})+$ Neem cake $(5 \mathrm{~kg} / \mathrm{plant})+$ Karanj cake $(5$ $\mathrm{kg} /$ plant), $\mathrm{T}_{3}$-Vermicompost (10 kg plant) $+50 \% \mathrm{NPK}, \mathrm{T}_{4}$-Vermicompost (10 $\mathrm{kg} / \mathrm{plant})+50 \% \mathrm{NPK}+P S B(20 \mathrm{~g} / \mathrm{plant}), \mathrm{T}_{5}$-Vermicompost $(10 \mathrm{~kg} /$ plant $)+$ $50 \%$ NPK + Azotobacter (20 g/plant), $\mathrm{T}_{6}$-Neem cake $\left.5 \mathrm{~kg}+50 \% \mathrm{NPK}\right), \mathrm{T}_{7}$ - Neem cake $5 \mathrm{~kg}+50 \% \mathrm{NPK}+P S B(20 \mathrm{~g} / \mathrm{plant}), \mathrm{T}_{8}$-Neem cake $5 \mathrm{~kg}+50 \% \mathrm{NPK}+$ Azotobacter (20 g/plant), $\mathrm{T}_{9}$-Karanj cake ( $5 \mathrm{~kg} /$ plant $)+50 \% \mathrm{NPK}, \mathrm{T}_{10}$-Karanj cake $(5 \mathrm{~kg} /$ plant $)+50 \% \mathrm{NPK}+P S B(20 \mathrm{~g} /$ plant $), \mathrm{T}_{11^{-}}$Karanj cake $(5 \mathrm{~kg} /$ plant $)+50 \%$ NPK + Azotobacter $(20 \mathrm{~g} /$ plant $), \mathrm{T}_{12}$-Vermicompost $(10 \mathrm{~kg})+$ Neem cake $5 \mathrm{~kg}+25 \% \mathrm{NPK}, \mathrm{T}_{13^{-}}$Vermicompost $(10 \mathrm{~kg})+$ Neem cake $(5 \mathrm{~kg})+$ $25 \%$ NPK $+P S B(20 \mathrm{~g} /$ plant $), \mathrm{T}_{14}$-Vermicompost $(10 \mathrm{~kg})+$ Neem cake $(5 \mathrm{~kg})+$ $25 \%$ NPK + Azotobacter (20 g/plant), $\mathrm{T}_{15}$-Vermicompost $(10 \mathrm{~kg})+$ Karanj cake (5 kg / plant $)+25 \%$ NPK, $\mathrm{T}_{16}$-Vermicompost $(10 \mathrm{~kg})+$ Karanj cake $(5 \mathrm{~kg} /$ plant $)+25 \% \mathrm{NPK}+P S B(20 \mathrm{~g} /$ plant $)$ and $\mathrm{T}_{17^{-}}$Vermicompost $(10 \mathrm{~kg})+$ Karanj cake $(5 \mathrm{~kg} /$ plant $)+25 \% \mathrm{NPK}+$ Azotobacter $(20 \mathrm{~g} / \mathrm{plant})$. Result revealed that combination of vermicompost @ $10 \mathrm{~kg}+25$ per cent recommended dose of NPK $+5 \mathrm{~kg}$ Neem cake+ $P S B 20 \mathrm{~g}$ per plant significantly increased the quality components of pomegranate fruits in terms of TSS (16.95 $\circ$ Brix), TSS acid ratio (41.62), ascorbic acid (14.39 mg/100 g), total sugar (14.24\%) and organoleptic score (8.51) as well as leaf and soil nutrient status as compared to recommended dose of NPK (500g : 200g: 500g).
\end{abstract}

Copyright $@ 2018$ Meena et al., This is an open access article published under the terms of the Creative Commons Attribution License, which permits unrestricted use, distribution, and reproduction in any medium, provided the original work is properly cited.

Preferred citation: Meena CL, Meena RK, Sarolia DK, Dashora LK \& Singh D. 2018. Effect of integrated nutrient management on fruit quality of pomegranate cv. Ganesh. Journal of Agriculture and Ecology, 5: 67-75; http://doi.org/10.53911/JAE.2018.5108.

\section{Introduction}

Pomegranate (Punica granatum L.) is one of the important fruit crops of tropical and sub-tropical world. It is a native of Iran and the surrounding areas. The characteristic ability of the fruit to withstand harsh climatic condition makes it able to grow in hot arid region. It is grown for its cool and refreshing 
juice. The ripe fruit of pomegranate contain 12-16 per cent sugar and 1.5-2.5 per cent acid. Infect, it contains more sugar than apricots, plums, peaches and oranges. Besides being commercially important it has some medicinal value and is considered beneficial for the patients of leprosy, dysentery and diarrhea. The rind of the fruit contains about 30 per cent tannin which can be used for tanning leather. India ranks first in pomegranate production (21.9 lakh tonnes) in the world (Indian Horticulture Database 2017), contributing 60$70 \%$ to the international pomegranate trade by exporting $1-2 \%$ of the production (Jadhav \& Sharma 2007). In India, pomegranate is commercially cultivated in Maharashtra, Andhra Pradesh, Uttar Pradesh, Gujarat, Rajasthan, Tamil Nadu and parts of Karnataka where good quality fruits are produced due to dry and hot climatic conditions. In India, more than $70 \%$ of the total production is used as table purpose and there is a high demand of fresh fruits both in domestic and international market. For higher production of quality fruits in a sustainable manner application of nutrients at proper doses is very important. It is reality that proper dose of nutrients to be standardized for a set of agro-climatic conditions which in turn to be economically acceptable, viable and eco-friendly suitable. In India, most of the fertilizer recommendations in pomegranate on the basis of higher quantity of inorganic fertilizers like 500-1000 g N, 500 $\mathrm{g}_{2} \mathrm{O}_{5}$ and 250-500 $\mathrm{g} \mathrm{K}_{2} \mathrm{O}$ plant/year (Saraf et al. 2004; Sharma et al. 2018). The INM have been recognized to influence fruit quality of pomegranate. Therefore, an investigation was conducted to study the effect of integrated nutrient management on fruit quality of pomegranate cv. Ganesh.

\section{Materials and Methods}

In order to enhance the productivity of pomegranate orchard, an investigation was under taken at Maharana Pratap University of Agriculture and Technology, Udaipur (Rajasthan). The Experimental Block is located at $24^{\circ} 34^{\prime} \mathrm{N}$ latitude and $73^{\circ} 42^{\prime} \mathrm{E}$ longitude at an elevation of 582.17 meters above mean sea level. The soil of the experimental site is clay loam having soil $\mathrm{pH}$ of about 8.0 with electrical conductivity of $0.94 \mathrm{dSm}^{-1}$ and 0.71 per cent organic carbon. The available N, P and K were 282.1, 23.0 and $305.94 \mathrm{~kg} \mathrm{ha}^{-1}$ respectively. In fact, in arid and semiarid areas, low precipitation, extremes of temperature, high wind velocity, poor soil fertility, soil salinity etc. are the major constraints of farming. The pomegranate, though, it is a hardy plant to various biotic and abiotic stresses but needs proper management with respect to nutrition, moisture management and plant canopy architecture for obtaining economic return. In Rajasthan, mrig bahar crop is taken by withholding the water from May to June. In present investigation 5 years old pomegranate orchard of cultivar 'Ganesh' at distance of $4 \times 6 \mathrm{~m}$ was selected for the experiment. The manure and fertilizer treatments were applied in middle of June during both the year of experimentation. The first light irrigation was given immediately after application of treatment and thereafter one or two light irrigation were given before the onset of rains. The trees start growth by July with onset of rains, flowers in AugustSeptember and produced fruits during winter season (December-January). 
The experiment was laid out in Randomized Block Design (RBD) with four replications, considering four plants as treatment unit. The INM treatments comprised of inorganic fertilizers (NPK), organic manures (Vermi-compost and farm yard manure) and biofertilizers (Azotobacter, Azospirillum and PSB). The total treatment combinations were seventeen viz, $500: 200$ : 500 g NPK/plant $\left(\mathrm{T}_{1}\right), \mathrm{T}_{2^{-}}$Vermicompost $(10$ $\mathrm{kg} /$ plant $)+$ Neem cake $(5 \mathrm{~kg} /$ plant $)$ + Karanj cake (5 kg / plant), $\mathrm{T}_{3}$-Vermicompost $(10 \mathrm{~kg} \mathrm{/} \mathrm{plant})+50 \% \mathrm{NPK}, \mathrm{T}_{4^{-}}$ Vermicompost $(10 \mathrm{~kg} /$ plant $)+50 \% \mathrm{NPK}+$ PSB (20 g/plant), $\mathrm{T}_{5}$-Vermicompost $(10 \mathrm{~kg} /$ plant) $+50 \% \mathrm{NPK}+$ Azotobacter (20 $\mathrm{g} /$ plant), $\mathrm{T}_{6}$-Neem cake $5 \mathrm{~kg}+50 \%$ NPK ), $\mathrm{T}_{7}-$ Neem cake $5 \mathrm{~kg}+50 \% \mathrm{NPK}+$ PSB $(20$ g/plant), $\mathrm{T}_{8}$-Neem cake $5 \mathrm{~kg}+50 \% \mathrm{NPK}+$ Azotobacter (20 g/plant), $\mathrm{T}_{9}$-Karanj cake (5 $\mathrm{kg} /$ plant $)+50 \% \mathrm{NPK}, \mathrm{T}_{10}$-Karanj cake (5 $\mathrm{kg} /$ plant $)+50 \% \mathrm{NPK}+$ PSB (20 g/plant), $\mathrm{T}_{11}$ - Karanj cake (5 kg / plant $)+50 \% \mathrm{NPK}+$ Azotobacter (20 g/plant), $\mathrm{T}_{12}$-Vermicompost $(10 \mathrm{~kg})+$ Neem cake $5 \mathrm{~kg}+25 \% \mathrm{NPK}, \mathrm{T}_{13^{-}}$ Vermicompost $(10 \mathrm{~kg})+$ Neem cake $(5 \mathrm{~kg})+$ $25 \% \quad \mathrm{NPK}+P S B(20 \mathrm{~g} / \mathrm{plant}), \mathrm{T}_{14-}$ Vermicompost $(10 \mathrm{~kg})+$ Neem cake $(5 \mathrm{~kg})+$ $25 \%$ NPK + Azotobacter (20 g/plant), $\mathrm{T}_{15^{-}}$ Vermicompost $(10 \mathrm{~kg})+$ Karanj cake $(5 \mathrm{~kg} /$ plant $)+25 \%$ NPK, $\mathrm{T}_{16}$-Vermicompost (10 $\mathrm{kg})+$ Karanj cake (5 kg / plant) $+25 \%$ NPK + PSB (20 g/plant) and $\mathrm{T}_{17-}$ Vermicompost $(10 \mathrm{~kg})+$ Karanj cake $(5 \mathrm{~kg} /$ plant $)+25 \%$
$\mathrm{NPK}+$ Azotobacter (20 g/plant). Observations on quality characters were recorded as per standard methodology. The fully ripe fruits were selected for analysis of quality parameters namely TSS Brix ${ }^{0}$, TSS: acid, ascorbic acid, total sugar and organoleptic score as well as leaf and soil nutrient status at harvest. The data on various parameters were analyzed with M-STAT statistical package to test the significance of the treatments.

\section{Results and Discussion}

Application of inorganic fertilizers, organic manures and biofertilizers significantly improved the nutritional quality of pomegranate fruits in terms of TSS, acidity, TSS/acid ratio and sugar content as compared to control (Table 1). It is further evident from the data that application of organic manure and biofertilizers proved significantly superior over inorganic fertilizers treatment. However, among various treatments, the application of $10 \mathrm{~kg}$ vermicompost $+5 \mathrm{~kg}$ neem cake $+25 \%$ recommended dose of NPK $+20 \mathrm{~g}$ PSB $\left(\mathrm{T}_{13}\right)$ was found to be best treatment with respect to nutritional quality parameters of the fruit. This treatment also resulted in maximum TSS content of $16.95^{\circ}$ Brix, minimum acidity of 0.41 per cent, highest TSS/acid ratio of 41.62 , ascorbic acid content (14.39 mg/100g), reducing sugars $(12.82 \%)$, non reducing sugar (1.35\%), and total sugar (14.24\%) (Table $1 \&$ $2)$. These are in accordance with those of Yadav \& Rathore (2004) in ber and Ram et al. (2007) in guava.

Table 1. Effect of INM on chemical characteristics of pomegranate cv. 'Ganesh'

\begin{tabular}{lccccc}
\hline Treatments & $\begin{array}{c}\text { Organoleptic } \\
\text { rating }\end{array}$ & $\begin{array}{c}\text { Juice } \\
(\%)\end{array}$ & $\begin{array}{c}\text { TSS } \\
\left(\text { Brix }^{0)}\right.\end{array}$ & $\begin{array}{c}\text { Acidity } \\
(\%)\end{array}$ & $\begin{array}{c}\text { TSS / } \\
\text { Acid } \\
\text { Ratio }\end{array}$ \\
\hline $\begin{array}{l}\mathrm{T}_{1}-\mathrm{RDF}^{-1} \text { of NPK }(500: 200: 500 \mathrm{~g} \\
\left.\text { plant }^{-1}\right)\end{array}$ & 6.25 & 64.95 & 15.05 & 0.61 & 24.75 \\
& & & & &
\end{tabular}


$\mathrm{T}_{2^{-}} \mathrm{VC}(10 \mathrm{~kg})+\mathrm{NC}(5 \mathrm{~kg})+\mathrm{KC}$ $(5 \mathrm{~kg})$

$\mathrm{T}_{3}-\mathrm{VC}(10 \mathrm{~kg})+50 \% \mathrm{NPK}$

$\mathrm{T}_{4}-\mathrm{VC}(10 \mathrm{~kg})+25 \% \mathrm{NPK}+\mathrm{PSB}(20$ g plant $\left.{ }^{-1}\right)$

$\mathrm{T}_{5^{-}} \mathrm{VC}(10 \mathrm{~kg})+25 \% \quad \mathrm{NPK}+$ Azatobactor ( $20 \mathrm{~g} \mathrm{plant}^{-1}$ )

$\mathrm{T}_{6}-\mathrm{NC}(5 \mathrm{~kg})+50 \% \mathrm{NPK}$

$\mathrm{T}_{7}-\mathrm{NC}(5 \mathrm{~kg})+25 \% \mathrm{NPK}+\mathrm{PSB}(20 \mathrm{~g}$ plant $\left.^{-1}\right)$

$\mathrm{T}_{8^{-}} \quad \mathrm{NC} \quad(5 \quad \mathrm{~kg}) \quad+25 \% \quad \mathrm{NPK}+$

Azatobactor (20 g plant $\left.^{-1}\right)$

$\mathrm{T}_{9}-\mathrm{KC}(5 \mathrm{~kg})+50 \% \mathrm{NPK}$

$\mathrm{T}_{10^{-}} \mathrm{KC}(5 \mathrm{~kg})+25 \% \mathrm{NPK}+\mathrm{PSB}(20$ $\mathrm{g}$ plant $\left.{ }^{-1}\right)$

$\mathrm{T}_{11^{-}} \quad \mathrm{KC} \quad\left(\begin{array}{llll}5 & \mathrm{~kg}\end{array}\right)+25 \% \quad \mathrm{NPK}+$ Azatobactor ( $20 \mathrm{~g} \mathrm{plant}^{-1}$ )

$\mathrm{T}_{12^{-}} \mathrm{VC}(10 \mathrm{~kg})+\mathrm{NC}(5 \mathrm{~kg})+25 \%$

NPK

$\mathrm{T}_{13^{-}} \mathrm{VC}(10 \mathrm{~kg})+\mathrm{NC}(5 \mathrm{~kg})+25 \%$

NPK+ PSB ( 20 g plant $^{-1}$ )

$\mathrm{T}_{14^{-}} \mathrm{VC}(10 \mathrm{~kg})+\mathrm{NC}(5 \mathrm{~kg})+25 \%$

$\mathrm{NPK}+$ Azatobactor ( $20 \mathrm{~g} \mathrm{plant}^{-1}$ )

$\mathrm{T}_{15^{-}} \mathrm{VC}(10 \mathrm{~kg})+\mathrm{KC}(5 \mathrm{~kg})+25 \%$

NPK

$\mathrm{T}_{16^{-}} \mathrm{VC}(10 \mathrm{~kg})+\mathrm{KC}(5 \mathrm{~kg})+25 \%$

NPK+ PSB ( 20 g plant $^{-1}$ )

$\mathrm{T}_{17^{-}} \mathrm{VC}(10 \mathrm{~kg})+\mathrm{KC}(5 \mathrm{~kg})+25 \%$

NPK+ Azatobactor ( 20 g plant $^{-1}$ )
5.95

6.55

7.75

7.75

6.91

7.41

7.01

6.44

6.79

6.69

8.01

8.51

8.34

7.41

8.11

7.93
64.85

14.75

0.59

25.08

65.50

15.30

0.57

27.07

72.26

16.16

0.46

35.25

71.80

16.11

0.48

33.85

67.85

15.66

0.52

30.37

69.46

15.85

0.50

32.16

$69.03 \quad 15.73 \quad 0.50$

31.29

66.43

15.29

0.54

28.14

67.31

15.41

0.53

29.45

$\begin{array}{llll}66.90 & 15.52 & 0.54 & 29.03\end{array}$

73.54

16.40

0.53

29.45

76.60

16.01

0.41

41.62

76.26

16.87

0.45

36.59

70.96

16.95

0.54

29.03

76.30

16.71

0.42

40.75

$75.76 \quad 16.68$

0.49

32.85

\begin{tabular}{llllll}
\hline $\mathrm{SEm} \pm$ & 0.16 & 1.51 & 0.20 & 0.43 & 39.37 \\
$\mathrm{CD}(\mathrm{P}=0.05)$ & 0.46 & 4.23 & 0.56 & 0.44 & 38.15
\end{tabular}

$\mathrm{VC}=$ Vermicompost, $\mathrm{NC}=$ Neem cake, $\mathrm{KC}=$ Karanj cake $\mathrm{RDF}=$ Recommended dose of fertilizer

It is well documented fact that of organic fertilization on various aspects of incorporation of organic manures in the soils not only acts as store house of major and micro nutrients but also favorably improve physical, chemical and biological properties of the soils. These results are in agreement with Ranjan and Ghosh (2005). Thus potential role crop growth can be ascribed due to its direct effect on availability of vital nutrients along with physico-chemical and biological properties of soils and indirectly via release of growth hormones, vitamins and augmenting microbial population etc. during its process of 
decomposition (Naik \& Haribabu 2007; Ram $\&$ Rajput 2000). Similarly, the beneficial effect of $P S B$ on fruit quality with respect to TSS and acidity might be due to phosphate solubilising bacteria that solubilise the insoluble forms of phosphorus and make them available to the plants. The mechanism of stabilization appears to be acid metal reaction and thus dissolution and chelation of metal and release of phosphorus. These are also known to produce acids, vitamins, growth promoting substances like IAA, $\mathrm{GA}_{3}$, etc. which might improve the quality of fruits (Haneef et al. 2014).

Table 2. Effect of INM on reducing sugar, non reducing sugar and total sugar of pomegranate cv. 'Ganesh'

\begin{tabular}{|c|c|c|c|c|}
\hline Treatment & $\begin{array}{c}\text { Reducing } \\
\text { sugars } \\
\text { Content }(\%)\end{array}$ & $\begin{array}{l}\text { Non reducing } \\
\text { sugars }(\%)\end{array}$ & $\begin{array}{c}\text { Total } \\
\text { Sugar }(\%)\end{array}$ & $\begin{array}{l}\text { Ascorbic acid } \\
\text { (mg/100 ml } \\
\text { juice) }\end{array}$ \\
\hline $\begin{array}{l}\mathrm{T}_{1}-\mathrm{RDF} \text { of NPK }(500: 200: 500 \mathrm{~g} \\
\left.\text { plant }^{-1}\right)\end{array}$ & 10.85 & 1.15 & 12.06 & 10.76 \\
\hline $\begin{array}{l}\mathrm{T}_{2^{-}} \mathrm{VC}(10 \mathrm{~kg})+\mathrm{NC}(5 \mathrm{~kg})+\mathrm{KC} \\
(5 \mathrm{~kg})\end{array}$ & 10.82 & 1.14 & 12.03 & 10.52 \\
\hline $\mathrm{T}_{3}-\mathrm{VC}(10 \mathrm{~kg})+50 \% \mathrm{NPK}$ & 10.87 & 1.21 & 12.14 & 11.13 \\
\hline $\begin{array}{l}\mathrm{T}_{4^{-}} \mathrm{VC}(10 \mathrm{~kg})+25 \% \mathrm{NPK}+\mathrm{PSB} \\
\left(20 \mathrm{~g} \mathrm{plant}^{-1}\right)\end{array}$ & 12.27 & 1.32 & 13.66 & 13.72 \\
\hline $\begin{array}{l}\mathrm{T}_{5^{-}} \mathrm{VC}(10 \mathrm{~kg})+25 \% \text { NPK }+ \\
\text { Azatobactor }\left(20 \mathrm{~g} \mathrm{plant}^{-1}\right)\end{array}$ & 12.11 & 1.31 & 13.49 & 13.60 \\
\hline $\mathrm{T}_{6}-\mathrm{NC}(5 \mathrm{~kg})+50 \% \mathrm{NPK}$ & 11.52 & 1.27 & 12.85 & 12.66 \\
\hline $\begin{array}{l}\mathrm{T}_{7^{-}} \mathrm{NC}(5 \mathrm{~kg})+25 \% \quad \mathrm{NPK}+\mathrm{PSB} \\
\left(20 \mathrm{~g} \mathrm{plant}^{-1}\right)\end{array}$ & 11.86 & 1.30 & 13.23 & 13.21 \\
\hline $\begin{array}{llll}\mathrm{T}_{8^{-}} & \mathrm{NC} \quad(5 \quad \mathrm{~kg})+25 \% & \mathrm{NPK}+ \\
\text { Azatobactor } & \left(20 \mathrm{~g} \mathrm{plant}^{-1}\right)\end{array}$ & 11.77 & 1.29 & 13.13 & 12.76 \\
\hline $\mathrm{T}_{9^{-}} \mathrm{KC}(5 \mathrm{~kg})+50 \% \mathrm{NPK}$ & 11.02 & 1.21 & 12.30 & 11.86 \\
\hline $\begin{array}{l}\mathrm{T}_{10^{-}} \mathrm{KC}(5 \mathrm{~kg})+25 \% \mathrm{NPK}+\mathrm{PSB}( \\
\left.20 \mathrm{~g} \mathrm{plant}^{-1}\right)\end{array}$ & 11.49 & 1.23 & 12.79 & 12.29 \\
\hline 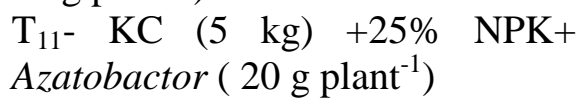 & 11.32 & 1.24 & 12.62 & 12.18 \\
\hline $\begin{array}{l}\mathrm{T}_{12^{-}} \mathrm{VC}(10 \mathrm{~kg})+\mathrm{NC}(5 \mathrm{~kg})+25 \% \\
\mathrm{NPK}\end{array}$ & 12.40 & 1.32 & 13.78 & 12.29 \\
\hline $\begin{array}{l}\mathrm{T}_{13^{-}} \mathrm{VC}(10 \mathrm{~kg})+\mathrm{NC}(5 \mathrm{~kg})+25 \% \\
\mathrm{NPK}+\mathrm{PSB}\left(20 \mathrm{~g} \mathrm{plant}^{-1}\right)\end{array}$ & 12.82 & 1.35 & 14.24 & 14.39 \\
\hline $\begin{array}{l}\mathrm{T}_{14^{-}} \mathrm{VC}(10 \mathrm{~kg})+\mathrm{NC}(5 \mathrm{~kg})+25 \% \\
\mathrm{NPK}+\text { Azatobactor }\left(20 \mathrm{~g} \mathrm{plant}^{-1}\right)\end{array}$ & 12.71 & 1.34 & 14.12 & 13.84 \\
\hline $\begin{array}{l}\mathrm{T}_{15^{-}} \mathrm{VC}(10 \mathrm{~kg})+\mathrm{KC}(5 \mathrm{~kg})+25 \% \\
\mathrm{NPK}\end{array}$ & 11.97 & 1.31 & 13.35 & 12.18 \\
\hline $\begin{array}{l}\mathrm{T}_{16^{-}} \mathrm{VC}(10 \mathrm{~kg})+\mathrm{KC}(5 \mathrm{~kg})+25 \% \\
\mathrm{NPK}+\mathrm{PSB}\left(20 \mathrm{~g} \mathrm{plant}^{-1}\right)\end{array}$ & 12.62 & 1.34 & 14.03 & 14.30 \\
\hline $\begin{array}{l}\mathrm{T}_{17^{-}} \mathrm{VC}(10 \mathrm{~kg})+\mathrm{KC}(5 \mathrm{~kg})+25 \% \\
\mathrm{NPK}+\text { Azatobactor }\left(20 \mathrm{~g} \mathrm{plant}^{-1}\right)\end{array}$ & 12.56 & 1.33 & 13.96 & 13.42 \\
\hline SEm \pm & 0.18 & 0.04 & 0.18 & 14.14 \\
\hline $\mathrm{CD}(\mathrm{P}=0.05)$ & 0.50 & 0.11 & 0.49 & 14.05 \\
\hline
\end{tabular}




\section{Leaf nutrient status at harvest}

The results of the experiment revealed that leaf nutrient status with respect to nitrogen; phosphorus and potassium content were increased over control after the termination of the trial due to various treatments (Table 3). The combined application of $10 \mathrm{~kg}$ vermicompost $+5 \mathrm{~kg}$ neem cake $+25 \%$ recommended dose of NPK $+20 \mathrm{~g} P S B$ was found to be significantly superior with $2.57 \% \mathrm{~N}, 0.46 \% \mathrm{P}$ and $1.76 \%$ $\mathrm{K}$ over 100 per cent recommended dose of NPK $(1.85 \% \mathrm{~N}, 0.35 \% \mathrm{P}$ and $0.37 \% \mathrm{~K})$. The leaf nutrient status was also significantly influenced by combined application of organic, inorganic and biofertilizers. The results of the present investigation are in conformity with the finding of Aseri et al. (2008) and Kumar \& Sharma (2017) who reported importance of vermicompost in the crop production. The results of the present investigation are in close agreement with the finding of Kumar et al. (2005) and Meena \& Bhati (2016) who also reported that the different levels of $\mathrm{N}, \mathrm{P}$ and $\mathrm{K}$ fertilizers significantly influenced leaf nutrient status. Similarly, the application of PSB @ 20 g per plant significantly increased $\mathrm{N}$ and $\mathrm{P}$ status of leaf at harvest, whereas, the $\mathrm{K}$ content of leaf was non-significant. Our results are in close agreement with the findings of Ram et al. (2005) and Naik \& Babu (2005) in guava.

\section{Available NPK status of soil}

The results of soil analysis at harvesting revealed that available nitrogen, phosphorus and potash content of soil significantly increased due to different treatments as compared to control (Table 3). The application of organic manures and biofertilizers were found to be significantly superior over 100 per cent recommended dose of NPK with respect to $\mathrm{N}$ and $\mathrm{P}$. The data further reveal that application of different levels of NPK treatment significantly increased the available NPK content of soil. Among the different treatments combined application of $10 \mathrm{~kg} \mathrm{VCM}+5 \mathrm{~kg}$ neem cake + $25 \%$ recommended dose of NPK $+20 \mathrm{~g} P S B$ showed higher fertility status of the soil in terms of $257.03 \% \mathrm{~N}, 29.65 \% \mathrm{P}$ and 319.60 $\% \mathrm{~K}$ content of soil as against 100 per cent recommended dose of NPK $(240.53 \% \mathrm{~N}$, $20.75 \% \mathrm{P}$ and $293.29 \% \mathrm{~K})$. It may be improvement in following use of vermicompost and neem cake. The results of the present investigation are in close agreement with the finding of Dey et al. (2005), who stated that the availability of phosphorus gets released from fixed phosphorus in the soil by the application of phosphate solubilising bacteria.

Table 3. Effect of INM on soil \& leaf N P K status

\begin{tabular}{|c|c|c|c|c|c|c|}
\hline \multirow[t]{2}{*}{ Treatment } & \multicolumn{2}{|c|}{$\begin{array}{l}\text { Nitrogen } \\
(\%)\end{array}$} & \multicolumn{2}{|c|}{$\begin{array}{l}\text { Phosphorus } \\
(\%)\end{array}$} & \multicolumn{2}{|c|}{ Potassium $(\%)$} \\
\hline & Soil & Leaf & Soil & Leaf & Soil & Leaf \\
\hline $\begin{array}{l}\mathrm{T}_{1}-\mathrm{RDF} \text { of NPK }(500: 200: 500 \mathrm{~g} \\
\left.\text { plant }^{-1}\right)\end{array}$ & 240.53 & 1.85 & 20.75 & 0.350 & 293.29 & 1.37 \\
\hline $\mathrm{T}_{2}-\mathrm{VC}(10 \mathrm{~kg})+\mathrm{NC}(5 \mathrm{~kg})+\mathrm{KC}(5 \mathrm{~kg})$ & 240.58 & 1.83 & 20.76 & 0.343 & 293.30 & 1.35 \\
\hline $\mathrm{T}_{3}-\mathrm{VC}(10 \mathrm{~kg})+50 \% \mathrm{NPK}$ & 241.30 & 1.91 & 21.17 & 0.356 & 295.76 & 1.41 \\
\hline $\mathrm{T}_{4}-\mathrm{VC}(10 \mathrm{~kg})+25 \% \mathrm{NPK}+\mathrm{PSB}(20 \mathrm{~g}$ & 251.30 & 2.37 & 26.56 & 0.431 & 313.78 & 1.63 \\
\hline
\end{tabular}




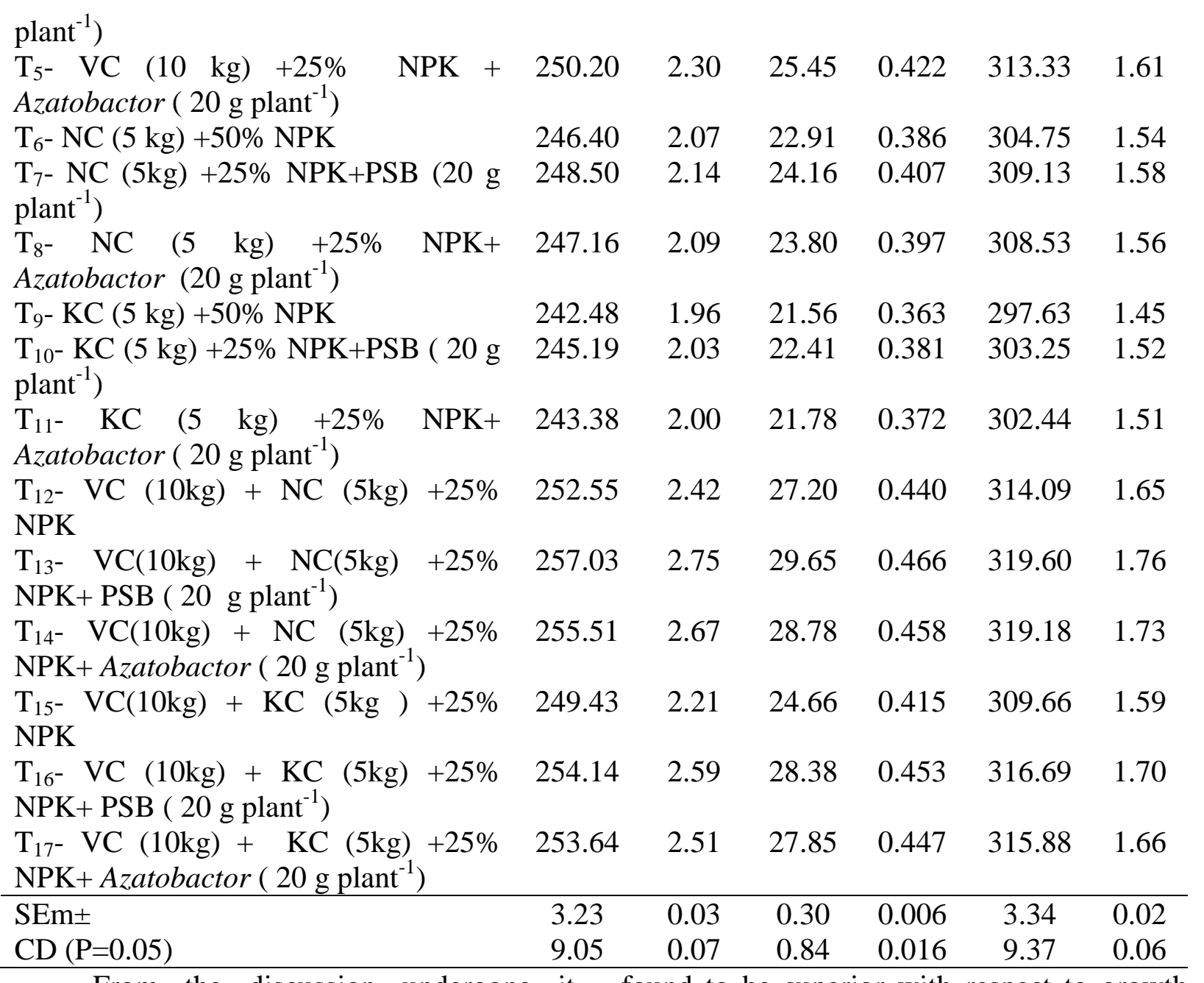

From the discussion undergone it found to be superior with respect to growth, becomes quite clear that different nutritional treatments in pomegranate significantly affected the growth, yield and quality of fruit. Among the different organic manure, the investigation revealed that the vermicompost was superior over the other organic manures in improving vegetative growth, flowering fruiting, yield and yield attributes and fruit quality. Further, the organic manures improved the soil fertility and leaf nutrient status of guava plant. This is conformity with finding of Shukla et al. (2009) and Balai et al. (2017). Similarly, among the different levels of inorganic fertilizer, the application of 25 per cent recommended dose of NPK was flowering, fruiting and yield of pomegranate. The application of PSB @ $20 \mathrm{~g}$ per plant also improved the growth and yield of pomegranate. These treatments were also found most economic in terms of net return and benefit cost ratio. Therefore, based on the findings vermicompost @ $10 \mathrm{~kg}$ per plant, 25 per cent recommended dose of NPK and PSB @ $20 \mathrm{~g}$ per plant in the month of June may be applied in pomegranate to obtain higher yield and quality fruits in pomegranate. The maximum net return (178843.20 Rs./ha) and $\mathrm{B} / \mathrm{C}$ ratio (3.72) recorded at $\mathrm{T}_{12}$ treatment i.e. $10 \mathrm{~kg}$ vermicompost $+5 \mathrm{~kg}$ neem cake +25 
per cent recommended dose of NPK + PSB @ 20 g/ plant.

\section{References}

Aseri GK, Jain N, Panwar J, Rao AV \& Meghwal PR. 2008. Biofertilizers improve plant growth, fruit yield, nutrition, metabolism and rhizosphere enzymes activities of pomegranate (Punica granatum L.) in Indian Thar desert. Scientia Horticulturae, 117: 13035 .

Balai RC, Meena LR \& Sharma SC. 2017. Effect of different levels of nitrogen and phosphorus on cowpea [Vigna unguiculata (L.) Walp] under rainfed conditions of Rajasthan. Journal of Agriculture and Ecology, 3: 19-24.

Dey P, Kumar S, Das B \& Nath V. 2005. Efficacy of biofertilizers in guava grown on acid soil. $1^{\text {st }}$ International Guava Symposium, Dec. 5-8, CISH, Lucknow, pp. 63-64.

Haneef M, Kaushik RA, Sarolia DK, Mordia A \& Dhakar M. 2014. Irrigation scheduling and fergitaion in pomegranate cv Bhagwa under high density planting system. Indian Journal of Horticulture, 71:45-8.

Jadhav VT. and Sharma, J. 2007. Pomegranate cultivation is very promising. Indian Hort. 52:30-31.

Kumar P, Tiwari JP \& Lal S. 2005. Effect of varying levels of $\mathrm{N}, \mathrm{P}$ and $\mathrm{K}$ fertilization on plant growth, yield, fruit quality and leaf nutrient status of guava (Psidium guajava L.) cv. 'Pant Prabhat'. $1^{\text {st }}$ International Guava Symposium. Dec. 58, CISH, Lucknow, pp. 80.
Kumar R \& Sharma OC. 2017. Saffron (Crocus sativus L.) growth and yield as influenced by organic farming practices. Journal of Agriculture and Ecology, 4:25-32.

Meena NK \& Bhati A. 2016. Response of Nitrogen, Phosphorous and Potassium Levels on Growth and Yield of Okra [Abelmoschus esculentus (L.) Moench.]. Journal of Agriculture and Ecology, 2: 17-24.

Naik MH \& Babu RSH. 2005. Feasibility of organic farming in guava. $1^{\text {st }}$ International Guava Symposium, Dec., 5-8, CISH, Lucknow, pp. 69

Naik MH \& Haribabu RS. 2007. Feasibility of organic farming in guava (Psidium guajava L.). Acta. Horticulturae. 735:365-72.

Ram RA \& Rajput MS. 2000. Role of biofertilizers and manures in production of guava (Psidium guajava L.) cv. 'Allahabad safeda'. Haryana Journal of Horticultural

Sciences, 29:193-194

Ram RA, Bhriguvanshi SR \& Pathak RK 2005a. Integrated plant nutrient management in guava (Psidium guajava L.) cv. 'Sardar'. $1^{\text {st }}$ International Guava symposium, Dec. 5-8, CISH, Lucknow, pp. 85.

Ram RA, Bhriguvanshi SR \& Pathak, RK 2007. Integrated plant nutrient management in guava (Psidium guajava L.) cv. Sardar. Acta Horticulturae. 735: 345-50.

Ranjan K, Tarai \& Ghosh SN. 2005. Effect of nitrogen levels on yield, fruit quality and foliar NPK status of aonla grown on 
laterite soil. Indian Journal of Shukla AK, Sarolia DK, Kumari B, Kaushik

Horticulture, 64:394-95

Saraf RK, Samaiya RK \& Shukla KC. 2004. Effect of different sources of nutrients on growth of pomegranate. Proceedings of National Conference on Biodiversity and Sustainable Utilization of Biological Resources, pp. 203-8.

Sharma SC, Balai RC \& Sahoo A. 2018. Effect of pasture type, phosphorus levels and phosphate solubilizing bacteria on forage productivity under agroforestry system in semi-arid regions. Journal of Agriculture and Ecology, 5: 42-49.
RA, Mahawer LN, \& Bairwa HL. 2009. Evaluation of substrate dynamics for integrated nutrient management under high density planting of guava cv. Sardar. Indian Journal of Horticulture, 66(4), 461-464

Yadav PK \& Rathore PS. 2004. Effect of foliar spray of thiourea and ferrous sulphate on the yield and quality of ber fruit. Progressive Agriculture, 4:85-86. 